Pasado y Memoria

ISSN: 2386-4745

Núm. 24, 2022, pp. 140-164

https://doi.org/10.14198/PASADO2022.24.06

Estudios

\title{
Discursos a través de la celebritat local: la cupletista Adela Margot a València durant la dècada de 1910
}

\author{
Discursos a través de la celebridad local: la cupletista \\ Adela Margot en Valencia durante la década de 1910
}

\section{Discourses through local celebrity: the cupletista Adela Margot in Valencia during the 1910s}

\author{
Isabel Ferrer Senabre \\ Investigadora independent, Espanya \\ isabel.ferrer.senabre@gmail.com \\ https://orcid.org/0000-0003-0150-6612
}

Recibido: 16/09/2021

Aceptado: 28/10/2021

Cómo citar este artículo: FERRER SENABRE, Isabel (2022). Discursos a través de la celebritat local: la cupletista Adela Margot a València durant la década de 1910. Pasado y Memoria. Revista de Historia Contemporánea, (24), pp. 140-164, https:// doi.org/10.14198/PASADO2022.24.06

\section{Resum}

Adela Margot fou una cupletista d'origen madrileny que va obtindre especial rellevància a València entre els anys 1911 i 1919, amb un ressò que ha perviscut fins a l'actualitat. L'estudi explora la idea que l'èxit de l'artista es va articular al voltant del conflicte sobre els espectacles que va enfrontar a les diferents ideologies polítiques presents aquell moment. A través de la figura de la Margot es va personalitzar la lluita per l'hegemonia discursiva d'allò considerat moralment desitjable en relació amb l'erotisme en escena, un protagonisme que va col-laborar en la popularització massiva del cuplet entre públic de la regió. Al mateix temps, Margot va recollir i va saber explotar els escàndols que esdevingueren al seu voltant per a mantindre l'estatus artístic mentre

(C)2022 Isabel Ferrer Senabre 
s'adaptava a les exigències dels canvis en els models femenins artístics de l'època. A través de la reconstrucció del recorregut biogràfic de l'artista, l'article aborda qüestions relatives a les dinàmiques de construcció de la celebritat local en interacció amb els discursos i productes culturals de l'entorn, participant en la comprensió global del fenomen de les estrelles en el gènere del cuplet.

Paraules clau: Celebritat; Cuplet; Sicalipsi; Escena local; Música; Restauració.

\title{
Resumen
}

Adela Margot, cupletista de origen madrileño, obtuvo especial relevancia en Valencia entre los años 1911 y 1919, con un eco que ha pervivido hasta la actualidad. El presente estudio explora la idea de que el éxito de la artista se articuló alrededor del conflicto sobre los espectáculos que enfrentó a las diferentes ideologías políticas presentes aquel momento. A través de la figura de la Margot se personalizó la lucha por la hegemonía discursiva de aquello considerado moralmente deseable en relación con el erotismo en escena, un protagonismo que colaboró en la popularización masiva del cuplé entre público de la región. Margot recogió y supo explotar los escándalos que acontecieron a su alrededor para mantener el estatus artístico mientras se adaptaba a las exigencias de los cambios en los modelos femeninos artísticos de la época. A través de la reconstrucción del recorrido biográfico de la artista, el presente trabajo aborda cuestiones relativas a las dinámicas de construcción de la celebridad local en interacción con los discursos y productos culturales del entorno, participando en la comprensión global del estrellato en el género del cuplé.

Palabras clave: Celebridad; Cuplé; Sicalipsis; Escena local; Música; Restauración.

\begin{abstract}
Adela Margot, a cupletista born in Madrid, enjoyed special relevance in Valencia from 1911 to 1919, with a certain repercussion that has remained to date. Margot's performances confronted the different political ideologies of the time. This study explores the idea that the figure of Margot personalized the struggle for the discursive hegemony of what was considered morally desirable in relation to eroticism on stage. Said prominence contributed to the popularization of the cuplé among the public of the region. Margot managed to exploit scandal while maintaining her artistic status by adapting herself to the changes in the female artistic roles. Through the reconstruction of the artist's biography, this paper addresses questions related to the dynamics of the construction of local celebrity while interacting with the discourses and cultural products located in that area, participating in the global understanding of the cuplé star system.
\end{abstract}

Keywords: Celebrity; Cuplé; Eroticism; Local Scene; Music; Restauration. 


\section{Introducció}

Des de fa no massa anys, els estudis al voltant dels espectacles escènics i les celebritats esdevenen un dels terrenys més fèrtils per a explorar els fenòmens culturals populars de l'època restauracionista. Entre aquest entramat d'oci -constituit, entre altres, pels cafès concert, les casetes de fira, els music-halls, els teatres de varietats i el nouvingut cinema- el cuplet emergí com un gènere capaç d'aglutinar els trets característics de la modernitat de principis del segle Xx. Escènicament, el cuplet es construí sobre una amalgama d'elements musicoteatrals que bevien del passat líric hispànic -sarsueles i tonadilles-, del couplet francès, del puixant flamenquisme i, sobretot, de la personalitat que les cantants aportaren a les performances unipersonals.

Però, indefectiblement, la conformació de l'espectacle cupletístic va anar lligada a la sociabilitat pròpia de les ciutats d'aquell temps. Més que un gènere musical, el cuplet fou una actitud ubiqua, indestriable del pols urbà en la seua vessant pública i mediàtica, però també privada (Encabo, 2019a: 11). En el seus inicis, el cuplet esdevingué sinònim de sicalipsi, d'erotisme en escena, de capacitat de subversió dels valors tradicionals en un moment en el qual s'estaven expandint amb força noves possibilitats d'emancipació femenina. ${ }^{1} \mathrm{Al}$ mateix temps, les cupletistes estigueren sotmeses al règim d'especularització i mercantilització del cos de la dona, i restaren fortament vinculades, tant de forma real com a nivell discursiu, als mons marginals i a la prostitució (Clúa, 2016). Així, la potent empremta del cuplet i les seues protagonistes va provocar la necessitat de negociar, des de totes les ideologies del moment, quins havien de ser els espais i les narratives sobre les artistes i quins els models femenins que s'hi haurien de desprendre, els quals acabaren basculant entre la polaritat d'àngel de la llar i àngel caigut; en altres paraules, un conjunt d'interpretacions encabides dins de l'ordre patriarcal que anaren des de la mistificació i l'atracció fins a la condemna (Navarro, 2015).

Actualment, aquesta interpretació del fet cupletístic també conviu amb la idea que les artistes d'aquell moment construïren la seua pròpia agència, amb una capacitat d'influència, una autosuficiència econòmica i un mode de vida molt distint de les dones del moment, essent un model on emmirallar-se. Progressivament, s'han destriat quins foren els mecanismes que generaren que les cupletistes més reeixides arribaren a obtindre aquesta repercussió, com

1. En relació al concepte de 'sicalipsi', podeu llegir el resum sobre el diferents significats que va acollir a Zubiaurre (2014: 17-19). Pel cas que ens ocupa, és rellevant remarcar que hi ha especialistes, com ara Anastasio (2007: 193), que empren el terme com a sinònim del context eròtic del cuplet de l'època d'entre segles, prèvia a la segona dècada del segle XX. 
ara la construcció d'un personatge identificable per al públic a través de la música, el cos, el text i la performance; la gestió del propi relat i imatge a través de la premsa i la fotografia; o la utilització de diverses fórmules per a reforçar l'alteritat amb els models femenins establerts (Clúa, 2016).

A l'estat espanyol, bona part de l'estudi de les cupletistes ha estat protagonitzat pels treballs basats en l'anàlisi de les grans estrelles del gènere. ${ }^{2}$ Tanmateix, aquestes grans estrelles foren només la cúspide d’una professió formada per una gran quantitat de dones que aspiraren a devindre una celebritat però que romangueren formant part d'allò que Salaün (1990) ha qualificat com a "proletariado del espectáculo». En aquesta categoria hi trobaríem des de la cupletista media -amb «horarios nocturnos, interacción con gente de la faràndula $[\ldots]$ y un vinculo económico con la burgesia a través de una relación de proteccionismo» (Navarro, 2015: 7)- fins a les artistes que es guanyaven la vida als escenaris i les habitacions d'espais marginals. Però, entre aquest gruix de professionals, romanen inexplorades algunes cupletistes, de fama relativament efímera, que es van caracteritzar pel seu nexe amb l'escena local. ${ }^{3} \mathrm{~A}$ pesar que el seu èxit no va ser comparable a les grans figures del gènere, aquest text té la finalitat última de demostrar que el seu paper va ser imprescindible a l'hora d'acostar el cuplet al públic a través d'un vincle de proximitat, un fet que les separava conceptualment de les grans celebritats del gènere escènic. Així mateix, la seua anàlisi ens permet també arribar a comprendre com es va articular l'escena local integrant-hi altres actors socials del moment pertanyents a la política, la premsa o l'empresariat. També són elles qui ens permeten accedir a les maneres de viure el gènere del cuplet fora de les grans ciutats, un terreny del tot esmunyedís a causa del seu minse rastre documental.

Quan parlem d'escenes locals durant la Restauració, un moment caracteritzat per la tendència cap a l'homogenització dels patrons i gustos culturals, és imprescindible referir-se a l'articulació del fet nacional entre els àmbits local, regional i estatal. Si bé en les pàgines següents l'anàlisi d'allò relacionat amb les qüestions pàtries rebrà una atenció tangencial, per a pensar el cuplet en tota la seua magnitud, han estat del tot inspiradors els arguments que vinculen l'existència de multitud d'escenes culturals desenvolupades «des de

2. Vegeu, per exemple, els esmentats treballs de Clúa (2016) i Navarro (2015), a més d'Encabo (2014 i 2019b), Anastasio (2009) o García Carrión (2015 i 2017).

3. Entre les definicions que es manegen des dels estudis musicològics per a definir la concepció d'escena musical, tot i no haver-hi una definició tancada, se n'ha destacat la pertinença a un determinat context espacial i temporal; la participació individual i collectiva de diversos agents (des d'artistes fins a la premsa); l'existència d'espais de difusió; la necessària interacció amb el públic que genere una esfera simbòlica, i, per últim, el vincle que uneix allò local amb allò global (Pedro et al., 2018). 
baix», lligades a un territori d'abast local o regional, amb la creació d'una esfera pública comuna nacional (Archilés, 2002; Archilés i García Carrión, 2012). En el cas del cuplet, és l'escena madrilenya d'on emergiren moltes de les creacions culturals que marcaren l'esdevindre del gènere. Però és en els estudis sobre l'escena barcelonina (Anastasio, 2007; Navarro, 2015; Molner, 2017; Planagumà-Clarà, 2020) on es treballa amb la idea que el Paral.lel va acollir els encontres i divergències entre les classes populars i burgeses, entre els diferents models de ciutat segons les diferents ideologies polítiques i on es contempla el paper que van jugar els nacionalismes en el desenvolupament del gènere. Hi ha altres escenes, però, com és el cas de la valenciana, on les actituds al voltant del cuplet encara no han estat treballades en profunditat. ${ }^{4}$

Per això mateix, aquest treball exposa un primer acostament al desenvolupament del cuplet en l'escena valenciana a través de la figura d'Adela Margot. La Margot, de nom real Adela Vicente, va ser una cupletista d'origen madrileny que va obtindre especial rellevància a València entre 1911 i 1919, amb un ressò que ha perviscut fins a l'actualitat. La hipòtesi del treball és que la figura de Margot va personalitzar la lluita per l'hegemonia discursiva al voltant d'allò moralment desitjable en relació amb l'erotisme en escena; així mateix, el seu protagonisme va col-laborar en la difusió del cuplet per mitjà de diferents productes culturals locals que acostaren el gènere al públic de la regió.

Així, l'estudi es construeix sobre la idea que les estrelles de l'espectacle representen i transmeten valors, visions, actituds i creences de grups socials, articulant allò públic i privat, en estreta relació amb els mitjans de comunicació (cf. Dyer, [1979] 2001; Marshall, [1997] 2014). S'hi assumeix que les celebritats acostumen a ser fenòmens globals però, simultàniament, poden tindre un esdevenir específic en un entorn determinat, de caire regional o local, allotjant possibles capes d'interpretació i d'adscripció identitària, en el seu sentit més ampli (cf. Ferris, 2010). En aquest sentit, és l'enfocament biogràfic aquell que, en el cas que es presenta ací, ha permès problematitzar d'una forma més rica el continu de fenòmens al voltant de la celebritat local.

Fent servir el recorregut vital de la protagonista, primerament es descriu quins foren els processos mitjançant els quals la Margot va arribar a protagonitzar la disjuntiva sobre la moralitat en el teatre de l'escena valenciana de principis de segle; en segon lloc, aborda de quines formes l'artista va recollir i va saber explotar els escàndols que van esdevindre al seu voltant al mateix temps que s'adaptava a les exigències que imposaven els canvis en els models

4. Sobre el teatre i música escénica valenciana de l'època hi trobem els estudis de Galbis López (1997), Blasco Magraner i Bueno Camejo (2015) i Bojó Molina (2020). 
femenins de l'època; i, per últim, s'aprofundeix en l'examen dels processos i produccions culturals entorn de la cupletista per tal d'integrar allò estudiat als discursos sobre les celebritats femenines de la dècada de 1910 .

\section{La Restauració va al teatre}

El 31 de gener de 1912, el periòdic conservador La Voz de Valencia-òrgan periodístic de la Liga Católica- incloïa en la seua portada una vinyeta del dibuixant K-Hito. La il.lustració la protagonitzava una dona amb un vestit llarg que, asseguda i lligada a una cadira, havia estat apunyalada amb dos sengles ganivets. En les fulles dels tallants es llegia «Palacio de Cristal» i «Salón Novedades». Al fons de l'escena principal de la vinyeta, dos policies passejaven xiulant tranquils, mentre simulaven no saber-ne res (Il-lustració 1). La metàfora sembla clara: la dona representava la moralidad que estava sent «assassinada» per la tipologia d'espectacles que s'oferien en aquests dos locals, davant la inacció dels agents de la llei, un fet que es criticava des d'un periòdic ultraconservador.

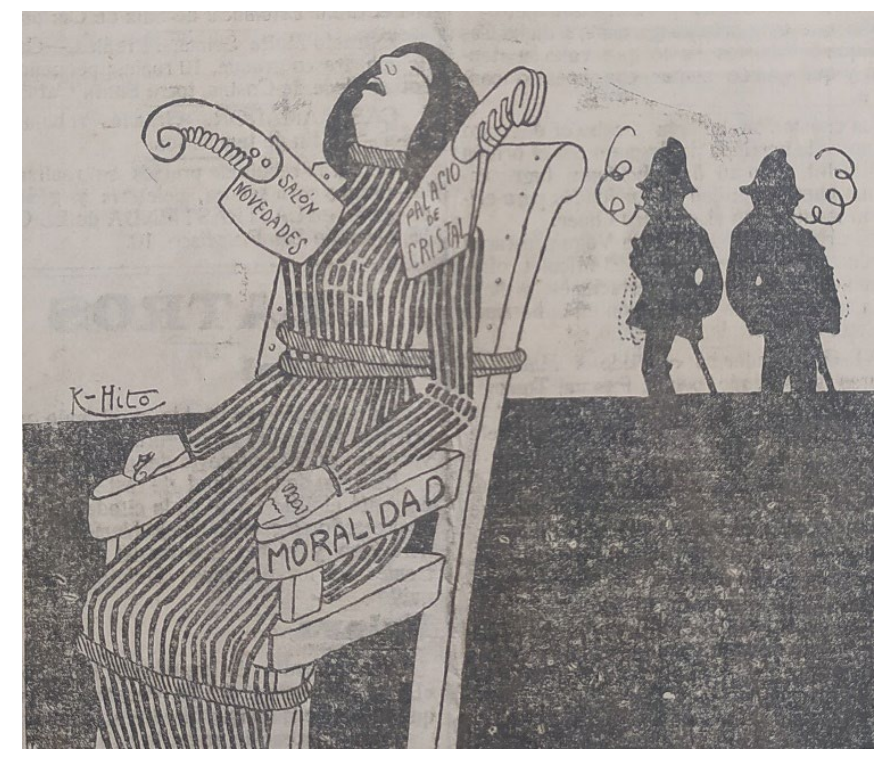

Il-lustració 1: La Voz de Valencia, 31/01/1912, p. 1.

Analitzant la situació amb una mica més de profunditat, però, és fàcil aventurar que la vinyeta també arrossegava altres crítiques de caire ideològic i polític. De fet, des de principis de 1912, La Voz mantenia un agre debat en 
matèria d'espectacles amb El Pueblo, el periòdic dels republicans blasquistes. ${ }^{5}$ Pel que es desprèn de la premsa, hi hagué dos desencadenants que ajudarien a explicar per què el món de l'oci havia passat dels marges al centre en el gruix de notícies de la capital valenciana. El primer desencadenant fou la implantació d'un arbitri municipal sobre els teatres, un canvi en la recaptació de l'hisenda municipal relacionat amb les modificacions en la política fiscal aplicada pel govern de José Canalejas. El empresaris teatrals protestaren fefaentment contra l'impost; tanmateix, les negociacions amb les autoritats polítiques foren tan infructuoses que tots els teatres de València decidiren romandre tancats del 5 de febrer al 2 de març del 1912. ${ }^{6}$ La conjuntura fou aprofitada pel conservadors catòlics -especialment molestos per la coneguda com a "Ley del Candado»- ${ }^{7}$ per a secundar les queixes dels empresaris i atacar altres polítiques dels liberals; per la seua banda, el progressisme anticlerical va criticar-ne l'ús interessat per part dels conservadors de la repercussió negativa que tenia el tancament escènic per als treballadors, així com va apuntar que la mesura podia provocar una desbandada de públic masculí dels teatres cap als prostíbuls. ${ }^{8}$

La segona raó que feu passar els espectacles a la palestra política a través dels mitjans de comunicació foren les diatribes sobre la moralitat del cuplet i gèneres afins. El cuplet s'havia posicionat com una alternativa molt poderosa. ${ }^{9}$ Si bé a València hi tenim referències d'espectacles cupletístics des de principis de segle, fou a partir del 1910 -probablement arran de les actuacions de la Bella Chelito i La Fornarina en l'Exposició Nacional- ${ }^{10}$ quan el gènere va adquirir especial notorietat i presència regular a la premsa. S'ha d'esperar, però, fins a principis del 1912, per a presenciar la reacció airada dels catòlics. En aquest cas, una reacció vehiculada a través de la figura del regidor de la Liga Católica Pablo Meléndez. En aquell moment, Meléndez era l'únic edil de l'esmentat partit en el consistori de la ciutat, en un govern format per un amalgama de regidors de diferents presidits pel liberal Luís Bermejo. Segons El Pueblo, Meléndez havia estat escollit pels mateixos liberals per a exercir jurisdicció al districte del

5. Per a una anàlisi dels mitjans períodístics a la València del moment i les seues filiacions polítiques, vegeu Comes (1992).

6. «Los Empresarios y el ayuntamiento», La Voz de Valencia, 03/03/1912; «Conferensia de l'infern», La Traca, 02/03/1912.

7. L'esmentada «Ley del Candado» s'explica a Ortí (2004).

8. La Traca, 06/01/1912; «Conferensia en l'infern», La Traca, 24/02/1912.

9. Per a algunes personalitats de l'època relacionades amb el món de l'espectacle, això fou percebut -encara ho és en algunes publicacions actuals-com una situació de crisi teatral per la influència dels nous espectacles. Vegeu Blasco Magraner i Bueno Camejo (2015).

10. «Exposición Nacional en Valencia. La Fornarina», La Correspondencia de Valencia, 27/07/1910. 
Teatre, la zona de la ciutat on s'hi trobaven molts dels locals d'espectacles: ${ }^{11}$ el teatre Principal, que alternava òperes amb sarsuela i rebutjava les revistes o obres que albirava com a sicalíptiques; l'Apolo, que acollí operetes i sarsueles, a més de les actuacions de les principals cupletistes del moment; i, sobretot, dos teatres més xicotets, el Salón Novedades i El Palacio de Cristal, on s'oferien principalment varietats i espectacles de caire eròtic. ${ }^{12}$

El Salón Novedades no era la primera vegada que rebia crítiques sobre la «moralitat» dels seus espectacles. En maig del 1911 es manifestava des del conservadorisme que «diariamente ocurren escándalos y escenas bochornosas». ${ }^{13}$ Però fou qui Meléndez, al poc de temps d'exercir en el càrrec, va iniciar una campanya de denúncia amb que, segurament, també tenia l'objectiu de desgastar al governador. Els republicans d'El Pueblo no van dubtar en contraatacar-hi:

«Porqué si el concejal de la Liga Católica hubiese asistido á una sola audición en Novedades ó en el Palacio de Cristal, hubiera sufrido una decepción tremenda al encontrarse con caras conocidas de individuos de su gremio, desde periodistas, pasando por señoritos de la buena sociedad, hasta concejales de la derecha. Habría visto, quizás, á un concejal casi correligionario suyo, alternando con artistas en orgiástica cena y á punto de gritar como el personaje de "El género ínfimo": ¡la pulga, la pulga! Y si esto hubiese visto, ¿cón qué fuerza moral habría pedido al Gobernador que atara corto á empresas y canzonetistas? Seguramente al Sr. Meléndez lo absuelve el no haber asistido á ninguno de esos espectáculos, que suelen presenciar y aplaudir ¡hasta curas, Sr. D. Pablo, hasta curas! ¿Recuerdan los lectores aquellos núestros vaticinios de la última campaña electoral, cuando anunciábamos que, de triunfar las derechas, hasta en los cines y salones de varietees meterían el hocico les clericales? $»^{14}$

Durant tot el mes de gener de 1912, La Voz i El Pueblo seguiren alimentant el debat. Bàsicament, els conservadors es mostraven com els garants de «la cultura y buen nombre de la ciudad» ${ }^{15}$ mentre que els republicans afirmaven «que no defendemos los espectáculos sicalípticamente rabiosos. Allá el público con

11. «¡Sobre todo la moralidad!», El Pueblo, 09/01/1912.

12. A més dels esmentats teatres, la ciutat comptava amb el teatre Princesa, que va provar amb el género chico i paròdies teatrals; el Russafa, que seguia una línia d'espectacles propera a l'Apolo, si bé va apostar més pels espectacles lírics en valencià i d'altres locals més menuts que funcionaven com a music-halls i dels quals hi resta poca constància documental (Galbis López, 1997: 339-345). El Novedades i el Teatro de Cristal, segons un buidatge ràpid de la cartellera, havien passat d'oferir obres líriques i teatrals de xicotet format per a decantar-se cada vegada més per les varietats.

13. «Crónica de sucesos», Las Provincias, 25/05/1911.

14. «¡Sobre todo la moralidad!», El Pueblo, 09/01/1912.

15. La Voz de Valencia, 10/01/1912. 
sus gustos» ${ }^{16}$ al mateix temps que acusaven d'hipocresia als catòlics respecte a la sexualitat. En la polèmica també hi col-laborà la sàtira del progressisme anticlerical de La Traca, augurant un futur dels espectacles on els arguments dels catòlics serien un reducte del passat. ${ }^{17}$ En tot cas, els catòlics conservadors seguiren pressionant el govern, exigint denúncies sobre els espectacles al Novedades i al Palacio de Cristal.

Al cap i a la fi, però, tota aquesta polèmica acabaria augmentant l'efecte d'atracció vers els esmentats locals. Per aquelles dates, en el Novedades actuava la que en seria finalment la principal beneficiada de tot aquell escàndol: una cupletista, encara força desconeguda, de nom Adela Margot.

\section{D'Adela Vicente a Adela Margot: esdevindre una celebritat sicalíptica}

Adela Vicente Herrero havia nascut a Madrid, probablement a finals de la dècada de 1880. Provinent de família d'estrat popular però amb cert accés a recursos socials i educatius, va rebre formació en declamació, escriptura i música; de fet, va cursar la carrera de piano al Conservatori de Madrid, una consecució que li permetria, només finalitzar els estudis, muntar una acadèmia musical a Salamanca en companyia de les seues dues germanes (1901). ${ }^{18}$ Si bé les acadèmies privades femenines eren l'opció laboral més comuna i solvent per a les dones amb formació musical, uns anys més tard, Adela Vicente s'enrolà amb una companyia de teatre líric i varietats madrilenya, un canvi esperonat pel bon sou que rebien les artistes i que l'ajudaria a sostenir l'economia familiar. ${ }^{19}$

Sota la direcció d'Ernesto Tecglen Berben, entre 1908 i 1911 Adela Vicente va formar part de la companyia del Royal Kursaal, un teatre popular de la capital espanyola. ${ }^{20}$ Després de fer el salt a l'actuació en solitari -adoptant ja el nom artístic d'Adela Margot-, l'artista decidí iniciar una gira per províncies. A València la trobem per primera vegada en juliol de 1911 al teatre Apolo, anunciada com a monologuista amb l'obra Abajo la sicalipsis (1911), peça del mateix Tecglen

16. «jNosotros, inmorales!», El Pueblo, 11/01/1912.

17. La Traca, 27/01/1912.

18. Les classes de declamació a La Correspondencia de España, 08/07/1894. Sobre els estudis al Conservatori de Madrid hi ha referències a La Unión Católica, 22/06/1897 i a La Correspondencia de España, 05/07/1897. Lacadèmia de música de Salamanca apareix anunciada abundosament al periòdic El Adelanto (Salamanca) entre l'11/07/1901 i el 03/06/1902.

19. Letras y figuras, $54,10 / 02 / 1912$.

20. A Adela Vicente la trobem actuant a Madrid en nombroses referències de premsa entre juliol de 1908 (La Época, 05/07/1908) i maig de 1911 (La Correspondencia de España, 03/05/1911). 
i el músic Modesto Romero. ${ }^{21}$ La seua actuació a la ciutat rebé a la premsa una menció poc reeixida que incloïa, això sí, una xicoteta fotografia, seguint els mecanismes habituals a l'època en la presentació d'artistes. ${ }^{22} \mathrm{~A}$ partir d'octubre del mateix 1911 va marxar al Paral.lel de Barcelona, un dels epicentres del lleure del moment i visita obligada per a qui aspirava a guanyar-se la vida damunt dels escenaris. Allà va actuar al teatre Gayarre, on obtindria un èxit discret, sobretot tenint en compte la cupletista que actuava uns metres més enllà en el teatre Arnau: Raquel Meller, artista en ple moment d'ascens a la fama, i amb la qual seria comparada després. ${ }^{23}$ En tot cas, Margot tornà cap a València, passant a actuar en el respectable teatre Apolo al popular Salón Novedades. ${ }^{24}$

Aquesta vegada, però, el seu retorn va anar acompanyat d'un aparell mediàtic publicitari més contundent. Aquestes campanyes periodístiques presentaven a les cupletistes com a figures d'interès públic i sovint havien estat prèviament consensuades tant des de l'entorn de l'artista -mànagers, mecenes, etc.- com pels representants periodístics del corrents ideològics del moment. Laparició a la premsa, les fotografies i altres objectes gràfics, com ara les postals, tenien la finalitat de reconèixer i identificar a l'artista (Mendoza, 2018). A la revista valenciana Letras y figuras - publicació de tarannà liberal que alternava el seguiment de notícies nacionals amb cròniques locals-, les ressenyes sobre Margot foren regulars i positives, ${ }^{25}$ de fet, el continu de notícies sobre la cupletista a penes es va interrompre per la vaga dels teatres a la ciutat que tingué lloc, com s'ha esmentat en paràgrafs anteriors, en febrer de 1912. En el número aparegut el 10 de febrer, Letras y figuras la mostrava en portada i hi adjuntava una extensa entrevista. ${ }^{26} \mathrm{El}$ diàleg, que complia els cànons del gènere periodístic quan es tractava d'artistes, volia mostrar a una Margot culta, refinada i vinculada a la família, ressaltant-ne la seua formació, honestedat i capacitat de treball. Una persona, doncs, que en la vida fora dels escenaris es mantenia lluny de la imatge lligada a l'erotisme característic dels seus espectacles. Amb altres recursos periodístics i un estil molt diferent, també La Traca no dubtava en afirmar que «es la artista mimá del públic; cuant se’n vacha pareixerá que falte el sol en Valensia». ${ }^{27}$

21. El Pueblo, 04/07/1911 i 01/08/1911.

22. «Teatros y toros. Margot», Letras y figuras, 23, 06/07/1911.

23. Eco artístico (Madrid), 68, 15/10/1911, i 69, 15/11/1911. Per a saber-ne més sobre els canvis al voltant de la figura de Raquel Meller durant aquells anys, vegeu PlanagumàClarà (2020).

24. Letras y figuras, 45, 09/12/1911, i 51, 20/01/1912.

25. Letras y figuras, 49, 06/01/1912, i 50, 13/01/1912.

26. Letras y figuras, $54,10 / 02 / 1912$.

27. «Teatros», La Traca, 02/03/1912. 
En tot cas, tampoc seria del tot cert reduir la presència del cuplet en la València del moment a les actuacions de la Margot. En companyia d'innumerables artistes de varietats, foren Adela Lulú i La Goyita les estrelles més destacades, junt a altres que no arribaren a una fama tan àmplia, com ara Nieves Ferrer. De tota manera, tot i que actuaren de forma repetida a la ciutat, cap d'elles aconseguí crear la vinculació de tarannà identitari que va envoltar a la Margot. ${ }^{28}$

\section{Gestionar l'escàndol: La falla de la Margot}

Després del tancament dels teatres, Margot va reprendre les seues actuacions al Novedades a principis de març de 1912. Com hom sap, a València aquest mes està protagonitzat per les falles, una festa al voltant d'uns monuments efímers que, de forma més o menys satírica, representen aspectes de la realitat sociopolítica de la ciutat. En temps de la Margot, la durada de les falles es restringia al 18 i al 19 de març. La vespra, els rotatius exposaven quines eren les temàtiques de les falles i a la nit hi tenia lloc la plantà dels monuments; a l'endemà, dia de Sant Josep, passava el jurat que atorgava els premis i era la jornada en la qual la gent visitava les falles fins a la cremà nocturna. La festa, lluny de ser un element anecdòtic, acollia dins d'ella els valors contemporanis dels habitants de la València del moment, resumia la litúrgia col-lectiva festiva i simbòlica i mostrava de forma festiva tot un imaginari social que es difonia visualment en una societat amb altes taxes d'analfabetisme (Ariño, 1992). Vers el 1912, les temàtiques de les falles a poc a poc passaren de reflectir preocupacions locals a temàtiques d'abast més ampli, un fet que es va lloar des del blasquisme però va desagradar al sector conservador. ${ }^{29}$

De totes les falles d'aquell març va haver-hi una que va tindre un èxit acaparador: la falla que es va plantar a la Plaça del Doctor Collado, titulada oficialment La sicalipsis a la orden del dia, i ben prompte coneguda com La falla de la Margot, obra de l'artista faller Pere Guillem. Si bé no era, ni molt menys, la primera vegada que una falla s'hi referia als nous espectacles musicals i d'oci d'aquelles primeres dècades del segle Xx, La falla de la Margot va aconseguir passar a ser un dels monuments que es recordaria en el temps. De fet, La falla de la Margot ha rebut atenció des de nombroses publicacions, destacant-ne l'article de Medina i Sanchis (2012).

28. La Lulú, que actuava de forma puntual a la ciutat des del 1904 (El Pueblo, 15/09/1904) va treballar a finals del 1911 en el Novedades, per la qual cosa la revista Letras y figuras $(46,16 / 12 / 1911)$ li va dedicar la seua portada. Pel que fa a Pepeta Ramos, La Goyita, en aquell moment era encara una artista emergent que feia presagiar bones impressions (Letras y figuras, 52, 27/01/1912).

29. El Pueblo, 19/03/1912; Las Provincias, 18/03/1912. 
La història, segons la premsa, va anar de la següent manera. La comissió fallera va anunciar que la seua falla «representa un music-hall. A pie del escenario, donde canta una chanteuse, hay varios músicos que deben tocar algún aire encanallado. En las butacas se ven varios señores que parecen extasiados contemplando las desnudeces de la artista». ${ }^{30}$ Un cop plantada, però, la sorpresa fou que l'escenari s'assemblava al Novedades, la cupletista era físicament quasi idèntica a Adela Margot, darrere hi havia col-locat un sol -com havia predit, per casualitat o sense ella, La Traca- i, segons l'opinió popular, era fàcil distingir la identitats d'alguns membres del públic contemplant els ninots (Il-lustració 2). Si aquests ingredients no foren ja prou suggestius per a atraure públic, les pressions dels conservadors -que feren tapar amb més roba el ninot que representava a la cupletista- i les valoracions del jurat oficial -poc congruents amb l'apreciació popular-, multiplicaren la popularitat del monument i de l'artista que hi apareixia.

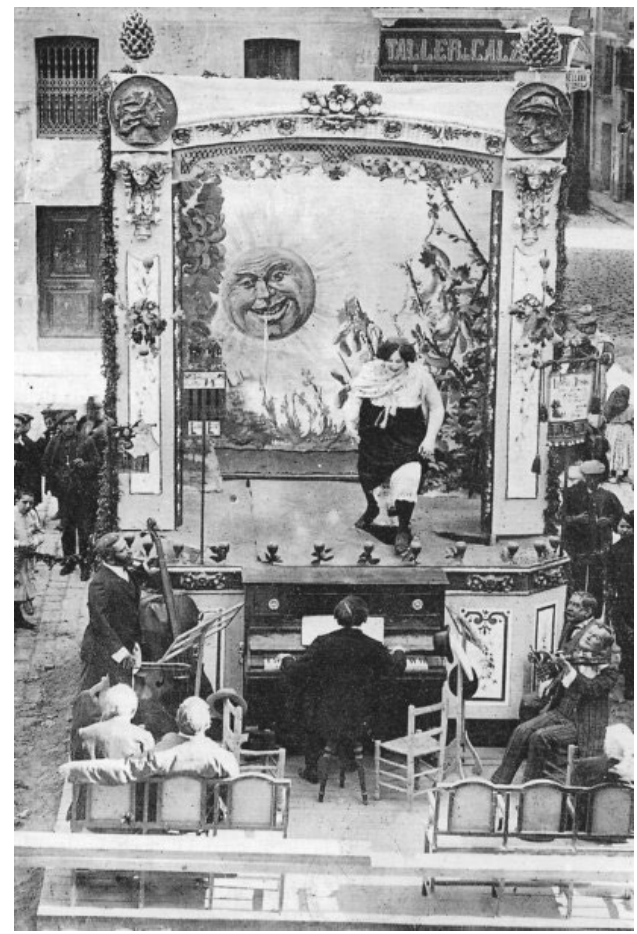

Il-lustració 2: La falla de la Margot. Plaça del Doctor Collado, València, 18-19/03/1912. Font: Soler Godes, 1978: 91. ${ }^{31}$

30. El Pueblo, 17/03/1912.

31. Agraïsc a Carles-Andreu Fernández, autor de la web Distrito Fallas, les referències sobre les fotografies del monument. 
Cal esmentar que al llibret escrit per la comissió fallera -uns fulls volants amb versos humorístics i satírics destinats a vendre'ls al veïnat per a recaptar fons-, apareixien referències a la realitat al voltant de la Margot. Aquesta literatura popular en vers -molt influenciada per la creació i transmissió oral-, de la mateixa manera que l'element visual dels monuments fallers, recreava l'imaginari col-lectiu, produint una sensació d'horitzontalitat i complicitat amb els lectors, alhora que entrava en el joc d'interessos sociopolítics a escala local.

Al llibret d'aquella falla, doncs, a la Margot se l'anomenava «La Changlot» i s'hi descrivien tots els llocs tòpics que acompanyaven el discurs de l'època sobre les cupletistes. En un diàleg inventat, dos homes debatien sobre com atansar la crítica sobre la cupletista («perque me fa molta por / dirli chufa a 'La Changlot'»). Els versos continuaven parlant de la centralitat de l'artista («Artista de novetat / segons alguns van dient / es Reina entre les estrelles»); del caràcter eròtic de l'actuació ( $Y \mathrm{Y}$ es tan fina y complasient / qu'enseña hasta les orelles / si li hu demana la chent»); del públic, format per homes d'edat avançada i classe popular ( «y eixe tio satisfet, / mirant-la, es torca la baba / mentre tremola de fret»); de l'actitud dèspota de la cupletista vers els músics («D'ells sols puc asegurar / que la pesa que'ella diga / al punt li l'han de tocar»); de l'assistència massiva i regular («Y els agüelos allí van / Una nit y un'atra nit, / com si alló tinguera imán») i de la maldat de la cupletista com qui s'aprofita de la debilitat masculina per a traure'n benefici econòmic («Ella els mira i se sonriu / fentlos dos mil posturetes, / Y en el seu interior diu: / Yo vos trauré les pessetes»). ${ }^{32}$ Així doncs, aquesta forma de literatura popular va fer seua la figura de la cupletista, al mateix temps que en reproduí tots els estereotips que carrejaven les artistes.

Amb tot, la Margot no va ignorar els beneficis a nivell professional i personal -dos àmbits indestriables en el cas de les cupletistes- que podia representar-li aquest cop de sort faller. Margot controlava perfectament les operacions que eren necessàries per a augmentar la seua fama, tant a nivell discursiu -ja hem vist la faceta que atenyia a la premsa- i a nivell performàtic, dins i fora de l'escena. Per a aprofitar l'escàndol faller i fer-lo seu, Margot va acudir ella mateixa a vore la falla (Il-lustració 3), feu una donació econòmica a la comissió de la Plaça Collado i pujà a un dels balcons de les cases de la plaça per a llançar unes paraules al públic. La mida del rogle al voltant d'ella i la gravetat dels altercats que es produiren varien segons el

32. Libret en la esplicasió y relasió que tot lo que conté la falla de la Plasa de Collado, 1912, Hemeroteca de València. 
tarannà ideològic del periòdic que narra els fets. La cloenda de tot plegat la marcà La Voz l'endemà de les falles, que va tornar a publicar en portada una vinyeta protagonitzada per una cupletista acompanyada per la seua mare, on s'hi feia referència a la tebiesa de les multes des de Governació vers aquesta tipologia d'espectacles i es lloava el fet d'haver cobert amb roba el ninot de l'artista (Il-lustració 4). ${ }^{33}$

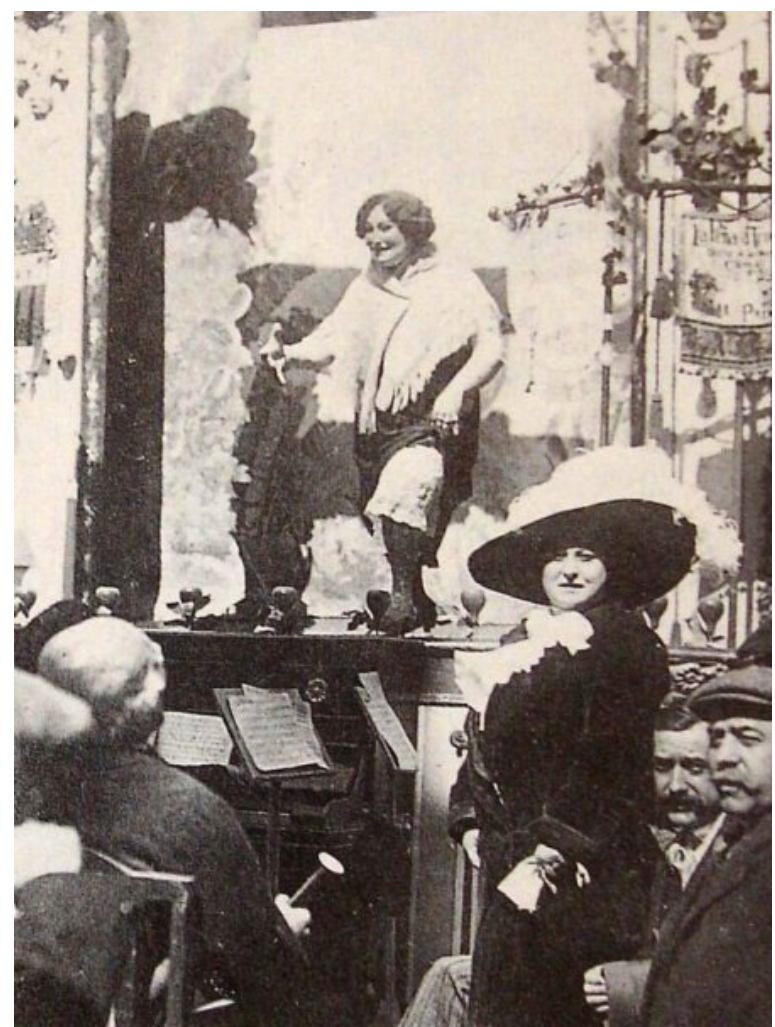

Il-lustració 3: Margot amb visitant la falla. Plaça del Doctor Collado, València, 19/03/1912. Foto: Arxiu J. Alcañiz. Font: Ariño et al., 1990: 154.

33. En les Il-lustracions 2 i 3 es pot apreciar com la figura que representaria a la Margot s'ha cobert amb tela en la part superior del tronc. 


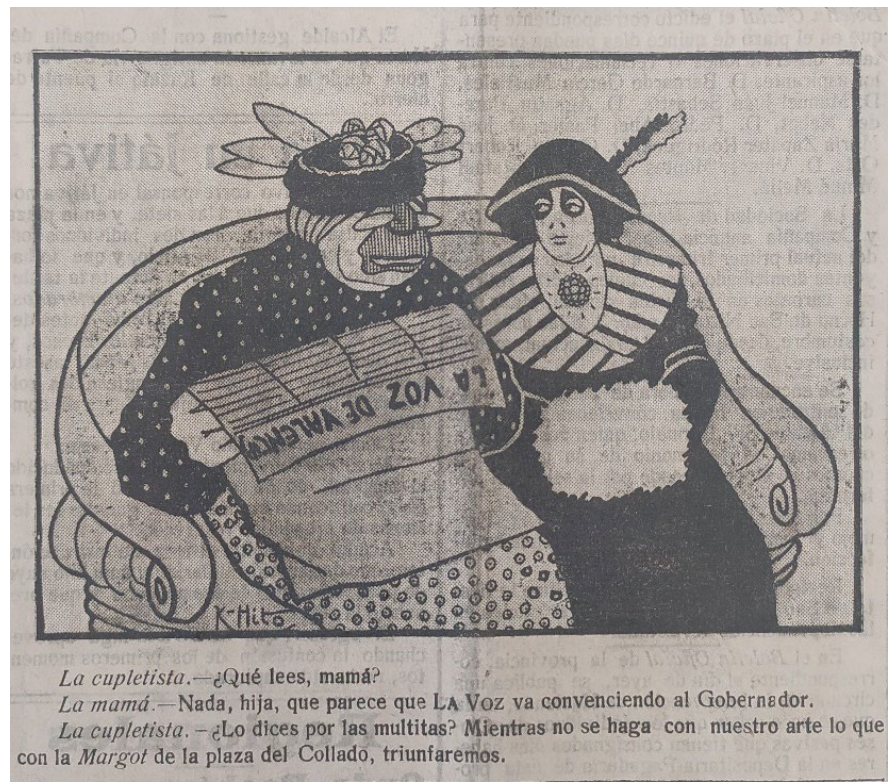

Il-lustració 4: La Voz de Valencia, 20/03/1912, p. 1.

La gent, però, volia més Margot. En abril del mateix any es va llançar una publicació periòdica que duia el seu nom -es desconeix si va tindre continuitat més enllà del primer número-i es conserva una minuta d'un sopar en un hotel de la ciutat en homenatge seu. ${ }^{34}$ Margot, com a bona cupletista, va seguir en l'estratègia de congeniar una imatge alhora propera i llunyana amb el públic a través de diferents mitjans: participà, com era també comú en els artistes del moment, en festivals benèfics, recolzant les vagues dels tipògrafs promocionada pel republicans d'El Pueblo; no va dubtar en emprar el vestit típic valencià en actuacions i actes; i va estendre rumors sobre els inicis d'una relació amb algú del món de la faràndula, com degudament filtrà la premsa progressista. ${ }^{35} \mathrm{De}$ fet, aquests mitjans de comunicació esdevingueren els seus principals valedors i publicistes. A més a més, l'oralitat va col-laborar en ampliar la seua fama per les rodalies de la ciutat, per a l'aparent infortuni dels conservadors: «En mi pueblo natal se habla de Adela Margot, de la hermosura de la Margot, del 'arte'

34. Revista La Margot, 1, 28/04/1912, Imp. J. Barberá, València (Hemeroteca de València). La minuta, de l'Hotel València amb data de 21 d'abril de 1912, es conserva en el fons privat de col-leccionista de la llibreria Maestro Gonzalbo de Carcaixent.

35. «La huelga de tipógrafos», El Pueblo, 02/05/1912; «De teló adins, saló Novetats», La Traca, 20/04/1912; La Traca, 04/05/1912. 
de la Margot. Y la Margot, tan ansiosamente esperada, aseudirá [?] en breve sobre un tablado, por millonésima vez, su corpachón desbordante de grasa y de atrevimientos». ${ }^{36}$

A finals de maig del mateix 1912, l'artista es va traslladar a Alacant, on se seguiren executant les operacions de promoció pròpies de les estrelles de l'època: es publicà un escrit autobiogràfic a un periòdic local, s'esbombà un suposat incident amb una altra cupletista, o l'artista va realitzar una donació a una família que demanava ajuda econòmica. ${ }^{37}$ D'allà, animada pels èxits obtinguts, va començar un pelegrinatge que la portaria a diferents ciutats espanyoles. Tanmateix, els temps per al cuplet estaven canviant.

\section{Estrella local per a uns models femenins canviants}

Diversos especialistes han esmentat la metamorfosi que va patir el cuplet a partir de la dècada del 1910. Se'ls considera els anys de «dignificació del gènere», uns moments en els quals es va advertir el trontoll que podria suposar per a la societat l'emergència d'un erotisme que mostrava certa autonomia professional i llibertat sexual per a les dones. També hi entraven en joc en la disjuntiva elements de classe, nació i política. Com afirma Navarro (2015: 22),

«un sector conservador y tradicionalista del país atacó el cuplé por estar asociado al espacio y al gusto populares, que se consideraban vulgares, y a lo extranjero, asociado con la inmoralidad. [...] El mundo del cuplé constituía un espacio en el que los moralistas percibieron el peligro de rebelión de las clases bajas y de la emancipación de la mujer, dada la gran influencia social del género».

Aquest fenomen, que es va mostrar de forma força diàfana a la ciutat de Barcelona, feu virar els espectacles del cuplet dels espais populars cap als admesos per la cultura burgesa. Per la seua banda, es va promoure un model de cupletista que aglutinara algunes de les característiques de «dona moderna» -amb un cos més esvelt i caracteritzat per la subtilesa en les maneres i la seducció-, sense deixar de banda la dona tradicional lligada a la cultura nacional o regional. Si bé aquest concepte de «dona moderna» a partir de la Primera Guerra Mundial va acollir significats múltiples, de vegades ambigus i no sempre amb un clar reflex real (Aresti, 2007), en el cas de les cupletistes i a partir de la dècada de 1920 va existir un esforç discursiu per fer conviure dins dels

36. Enrique Tormo: «Del terruño amado», Las Provincias, 10/06/1912.

37. Adela Vicente Herrero (Adela Margot): «Como soy. Pequeñas confesiones sinceras de una artista de varietés», Diario de Alicante, 01/06/1912; «Entre bastidores. La canción del violón», Diario de Alicante, 26/06/1912; Diario de Alicante, 27/06/1912. 
models que elles representaven factors com ara la seua gran presència pública, un erotisme de caire moderat i l'associació amb la regeneració pàtria que en permeteren la pervivència dins dels marges de la moralitat acceptada (Navarro, 2015; García Carrión, 2015 i 2017).

Pel que es desprèn de les publicacions, Margot va tractar de gestionar aquest important canvi. Tanmateix, les característiques del seu personatge i del seu espectacle no acabaven d'adequar-se a les noves maneres del gènere cupletístic. Tot i que ella pertanyia generacionalment al grup de cupletistes en boga -Pastora Imperio, La Goyita o Raquel Meller, per citar-ne algunes-, ben prompte se'n començaren a ressaltar les diferències conceptuals. De fet, al periòdic de tall conservador Las Provincias, el col-laborador Enrique Tormo era força clar amb les comparacions entre Margot i Raquel Meller en juliol de 1912:

«Sea lo que fuere, Raquel ha cambiado. Viste bien, canta mejor. Mueve su figulina con más chic. Y no es guapa, pero lo aparenta. ¿Prodigios de la química? No señor. Raquel no se embadurna. [...] Así parece de lejos.

Pero no hay que pasmarse. Todo lo pecaminoso que puede haber en Raquel, ya está dicho. Lo excelente, a medias. El espectáculo es todo lo "culto" que puede ser una función de las llamadas de varietés. Ahora, que Raquel dice algunas crudezas y algo más que crudezas. No es ninguna Margot. La Margot, sobre añorar el fregadero, es única con el gesto y el ademán. La Raquel está en la acera de enfrente. Pero entre la acera, donde, puesta en garras, lanza la Margot cada cerecilla capaz de dejar en carne viva las fauces de un arriero, y la acera donde la Raquel, muy gentilmente, arroja el tenue polvillo de su picante mostaza, está el arroyo por donde cruza cosquilleante y retozón, el diabólico couplet del pirulí...».38

Així, malgrat el seu únic «gesto y ademán», es considerava que Margot no era chic; més bé, tenia reputació de popular i contundent, fent ús d'un erotisme allunyat de tota subtilesa o puritanisme. Bona part del seu personatge es va basar en aquesta força, sense que hi siguen massa presents altres trets que explotaven les estrelles del moment, com ara el luxe, l'excentricitat o la fatalitat -trets sintetitzats per Clúa (2016). A Margot, en les actuacions dutes a terme durant el bienni 1913 i 1915, sovint se l'acusava d'oferir un espectacle de «mal gusto» $\mathrm{i}$ «funesto». Fins i tot, a Barcelona, trobem una entrevista on, a partir d'una confusió onomàstica entre Adela Margot i una artista emergent -Margarita, que s'havia posat de nom artístic Margot-, es feia un repàs força

38. Enrique Tormo: «Pizzicato, Pirulí, pirulá», Las Provincias, 07/07/1912. Val a dir, també, que l'article era una crítica a Víctor Margheritte i la seua defensa de les dones així com s'aprofitava per a comentar els canvis polítics espanyols al sí del partit liberal i les maniobres autonomistes de Francesc Cambó. 
punyent a la trajectòria de la cupletista mentre se la comparava, clarament a la baixa, amb la seua homònima més jove:

«Adela, con sus monólogos y desabillès, se conquistó un prestigio en los music-halls que se dedican a la sicalipsis, y Margarita, con su arte exquisito y netamente madrileño, sin necesidad de lucir sus camisas en el escenario, ni de decir cosas que no se avienen mucho con la discreción que debe tener una mujer. [...]

El arte de Adela, no tiene ninguna semejanza con el de Margarita. La primera es, si se quiere, una buena actriz cómica que sabe interpretar monólogos ligeros y la segunda, una cancionista que dice con original elegance canciones discretas y agradables. Es más, Margarita y Adela no pueden tener un mismo público. Para saborear el arte de nuestra Margot, es preciso un buen gusto [...] Difícilmente puede poseer aquella multitud que celebra con risotadas estrepitosas las palabras de doble sentido que figuran en las narraciones de Adela». ${ }^{39}$

En resum, l'article descriu què s'esperava de les «noves» cupletistes: reforç de la imatge de «puresa» i autenticitat territorial, a més de discreció en l'espectacle corporal i mesura verbal -una contenció que s'esperava també en les expressions del públic assistent durant l'espectacle. Per a cloure l'article de premsa, s'intentava aprofitar l'avinentesa de la confusió amb la finalitat de reforçar la rivalitat entre ambdues -més utilitària que no real- amb una comparació encara més transparent. Segons el text, Adela s'hauria molestat per la intrusió de Margarita i hauria passat a anunciar-se com a «Margot, la autèntica»; com a venjança, Margarita hauria passat a autoanomenar-se «Margot, la jove», alhora que marcava diferències conceptuals declarant-se admiradora i deixeble de Raquel Meller. Fora com fora, Adela Margot era allò desfasat, l'antiga sicalipsi, el cos voluptuós que ha passat de moda -una «mujeraza gordinflona y desenvuelta, regocijo de viejos verdes y pisaverdes agotados; [...] la bancarrota de la tradición, una desesperanza sin consuelo», segons el crític teatral de Las Provincias- ${ }^{40}$; per la seua banda, l'altra Margarita aspirava a ser allò nou i jove, portadora de la feminitat castissa alhora que atractiva, com insistia l'extensa entrevista de la revista barcelonina.

A València, però, Margot va tornar recurrentment, repetint triomfs i escàndols com els dels inicis del 1912. La dinàmica també es traslladava als teatres de les capitals de comarca, segons llegim de les actuacions a Gandia, Catarroja i Oriola: primer s'hi anunciava l'actuació de la Margot, després els periòdics conservadors i catòlics l'acusaven d'immoralitat -a ella i als promotors de

39. «Conversando con Margot», El Cine, 18/12/1915.

40. Enrique Tormo: «Del terruño amado», Las Provincias, 10/06/1912. 
l'actuació-, posteriorment els republicans anticlericals la defenien i la recolzaven, mentre ella seguia deixant la seua empremta en l'escena local. ${ }^{41}$

D'entre totes les situacions potencialment escandaloses, el cas més sonat va ocórrer al poble de Nules (Castelló) en 1916, quan es va haver de suspendre la seua actuació. Segons les fonts dels diferents rotatius, Margot va arribar a l'esmentada localitat en tren; a l'estació, es va trobar amb una airada protesta de les dones del poble, les quals s'oposaven a l'actuació de la cupletista. Finalment, malgrat la insistència dels homes que volien assistir-hi a la funció, l'alcalde va suspendre l'actuació. Només un any més tard, aquest suposat escàndol s'havia convertit en un sainet, titulat Cremáes sinse fóc: sainete valensiá en un acte, en vers y prosa, inspirat sobre el resibiment que li feren les dones en un poble de la provincia de Castelló a la chenial artista de varietés Adela Margot (escrit en el permís de ésta) (Gómez, 1917). L'obra va guanyar un premi a Lo Rat Penat -entitat valencianista de tall conservador-, tot i que no sabem si es va arribar a estrenar. D'entre totes les situacions similars on va participar l'artista, l'affaire Nules seria el que més empraria la protagonista a l'hora de construir la seua autobiografia.

Paral-lelament a la Margot, altres cupletistes de renom continuaren actuant a València. Adela Lulú, Pastora Imperio, Raquel Meller, la Argentinita o Resurrección Quijano comptaren amb el seguiment de la premsa, sense que se'n qüestionara massa la seua moralitat. Per a elles, el discurs estigué marcat per l'acceptació i promoció de les noves característiques del gènere cupletístic. Fins i tot Lulú, que no va canviar el tumultuós Novedades per altres teatres amb més recorregut -on hi actuaven la resta de cupletistes reeixides-va rebre el beneplàcit dels conservadors al seu «arte, más propio del público de los grandes teatros que del genero de las varietés». ${ }^{42}$ Per la seua banda, l'acceptació des de l'esfera popular i progressista valenciana es va moure entre diferents argumentacions, no sempre coherents. A grans trets, d'una banda, es tenia un posicionament positiu sobre les cupletistes i els seus espectacles, defenent-ne la llibertat d'assistència però, sobretot, cercant l'atac a la doble moral dels catòlics, com s'ha vist reflectit en paràgrafs precedent ( «Los neos a la caza de cupletistas», titularen un dels seus articles a El Pueblo). ${ }^{43}$ D'altra banda, el republicanisme en la seua versió blasquista es va preocupar per l'educació moral dels seus membres així com de la situació laboral de les dones que exercien la prostitució, encara que no per això s'evitaren els espais de lleure susceptibles de violència, beguda o joc (cf. Sanfeliu, 2002: 448; 2005: 78 i ss.).

41. Revista de Gandía, 29/06/1912, 26/04/1913, 05/05/1913 i 17/07/1915; El Pueblo, 09/05/1913 i 14/06/1913; El Conquistador (Oriola), 24/06/1916.

42. La Correspondencia de Valencia, 17/02/1914.

43. El Pueblo, 09/05/1913. 
En qualsevol cas, el seguiment més o menys regular que es va realitzar de les actuacions de la Margot entre 1912 i 1918 a diferents localitats mostra la seua popularitat, com es desprèn de les cròniques prèvies i posteriors. ${ }^{44}$ Dintre de la difícil recerca que suposa el seguiment dels espectacles escènics i musicals fora de les grans ciutats, les actuacions de l'artista obren la possibilitat a reconsiderar l'impacte del cuplet i de les cupletistes, amb els imaginaris i models que proposaven, entre el públic femení de les localitats de mida xicoteta i mitjana -seguint la línia d'allò exposat per Monlleó (2007) per als espectacles finiseculars.

No obstant això, la performance de la Margot no fou l'únic element que la portà a la fama. A més del poder del seu personatge i la càrrega eròtica de les funcions, bona part de l'èxit a l'escena local esdevingué gràcies a la vinculació amb la producció cultural local. En el cas de les actuacions a la ciutat de València, sabem que alguns dels autors més en boga de l'escena teatral popular local del moment, com foren Pere Chirivella i Josep Peris Celda, li escriviren monòlegs de nova creació. ${ }^{45}$ Posteriorment, algunes d'aquestes produccions es podien adquirir a l'acadèmia privada del músic de varietats Isidro Laguna - «Venta de la exclusiva de los monólogos Plátano, Niñerías, Agua y Abajo los pantalones, estrenados con gran éxito en el Salón Novedades, por Adela Margot». ${ }^{46}$

En aquest sentit, una de les actuacions que coneixem millor és la que es va dur a terme a Requena en juny de 1913, gràcies a què la conservació dels textos i músiques escrits ex professo per a aquella ocasió, i que amb probabilitat, s'hi inclourien en el repertori posterior de l'artista. ${ }^{47}$ Es tracta de tres cuplets, amb títols i continguts tan significatius com habituals en aquell moment: Madrileña, Valenciana i Española, amb música de Mariano Pérez i lletra de Fernando Belda. ${ }^{48}$ Gràcies a les partitures i les indicacions allà escrites, podem deduir

44. A més de les localitats esmentades (València, Alacant, Catarroja, Requena, Oriola i Nules), que hi haja constància documental, va actuar a Alzira i Carlet (Eco Artístico, 93, 15/06/1912, p. 18), Castelló i Alberic (Eco Artístico, 94, 25/06/1912, p. 11); Novelda (El combate, 31/05/1913), i Xàtiva (Correspondencia de Valencia, 12/08/1918).

45. La Traca, 20/01/1912; El Pueblo, 08/05/1919.

46. Arte, 1, 01/10/1912.

47. Eco Artístico, 15/06/1913; El Distrito (Requena), 15/06/1913.

48. Els materials de Requena els agraïsc al musicòleg Marcial Garcia Ballesteros, qui me'n va fer coneixedora, els ha cedit amablement $i$ ha atès generosament les meues consultes. Els manuscrits de les partitures per a veu i piano dels tres cuplets i un enregistrament posterior (17/11/1996) efectuat a Requena per part de la cantant Teresa Segarra i la pianista Clara Cabrera es poden trobar al Fons Mariano Pérez Sánchez de l'Arxiu Marcial García Ballesteros. També s'hi pot trobar una edició impresa dels cuplets per a piano en la revista Mundial Musical, 95 (1925) i referències de premsa a García Ballesteros (1996). 
part del desenvolupament de l'espectacle. Seguint la lògica d'aquells temps, l'espectacle el formarien algun monòleg -peça teatral breu amb moments musicals-acompanyat d'algun dels cuplets més famosos d'aquell temps, popularitzats per artistes de renom. A més, s'hi afegiren les peces de nova creació esmentades. Cadascun dels tres cuplets portava associat un vestuari regional, un estil musical i uns versos que lloaven les virtuts típiques de cada àrea geogràfica, sempre amb un doble sentit eròtic. A Madrileña li correspongué un xotis. A Valenciana la peça s'inicia amb reminiscències a les fórmules musicals de cançó de bressol característiques de la zona, entremesclada amb la melodia de l'U i el dos. Finalment, a España Margot apareixia a l'escenari coberta amb la bandera «roji-gualda» per a cantar un pasdoble que desentelava discursivament la dualitat territorial entre «el amor de la región / que a todos nos acompaña / y el amor de la nación / el amor de nuestra España».

\section{Conclusions. De Margot a Adela Vicente}

A partir de l'escàndol de Nules el 1916 i les noves circumstàncies que envoltaven els espectacles, Margot probablement va optar per modificar la seua estratègia professional. De les imatges se'n desprèn un posat més madur, la seua nomenclatura la definia ara com una canzonista i va tornar a emprar la seua vinculació a València com a reclam -una operació exitosa que ja hem vist que duia a terme des del $1912 .{ }^{49}$ Malgrat tot, de la quantitat d'actuacions publicitades es dedueix que la seua presència pública va anar reduint-se progressivament.

Així i tot, l'any 1919 Margot va tornar a reformular la seua carrera: va escriure un llibre autobiogràfic, que va titular Al Oído. El libro de la vida (Margot, 1919). El ressò que el volum tingué a l'estat espanyol fou força testimonial. Ans al contrari, la promoció del llibre a la premsa progressista valenciana fou entusiasta i constant en el temps. El Pueblo va publicar-ne el segon capítol, ${ }^{50}$ a més de successius anuncis setmanals, mentre que a $L a$ Traca aprofitaren a l'artista, de nou, per a remarcar el seu ideari anticlerical:

«Adela Margot, $[\ldots]$ no contenta en triunfar en l'essenari, ahon es reina y señora sobre totes les atropellaplats que al difisil art de les varietés se dediquen, ha vulgut tabé triunfar en el camp de la lliteratura [...].

Pero he así que Adela, la frívola y picaresca monologuista, tan discutida y vituperá per la chen d'orde, se mostra en son llibre, después de fer escrupulós

49. A La Traca (20/04/1912) no s'estigueren d'afirmar que la «Margot vestida de llauraora estaba ipera mencharsela!». Més tard, la trobem vestida de valenciana a Madrid en un reportatge extens a la revista Eco artístico $(284,15 / 10 / 1917$, p. 25$)$ i en la portada de la revista Mundo Gráfico (23/09/1923).

50. «Teatros. Adela Margot», El Pueblo, 14/07/1919. 
exame de consensia, tal cual es: seria, chuisosa y digna. Una cosa es l'artista en l'essenari y atra en la vida intima. La Margot, en la vida íntima, es un poc més recatá que eixes linajudes dames qu'enseñen els pits i l'esquena en la platea de un teatro. Mentres La Margot fa com qui enseña, éstes enseñen com qui no ho fa»..$^{51}$

No obstant això, a la fi, Margot va voltar per diferents ciutats, passant alguna temprada llarga a Tenerife per a instal.lar-se definitivament a Madrid. ${ }^{52}$ Allà va continuar reciclar-se professionalment gràcies a la seua formació. Així, a partir del 1924, va abandonar la cançó per a presentar-se, en successives publicacions, amb qualificatius com ara «ilustre escritora y virtuosa profesora de piano». ${ }^{53}$ Progressivament va abandonar la identificació d'Adela Margot per a tornar a signar com a Adela Vicente. A més d'aparèixer a la ràdio, sembla ser que va participar en recitals de poesia i en mítings a favor de l'abolició de la prostitució en companyia de personalitats com ara Maria Lejárraga. ${ }^{54}$ Finalment, es casaria $a m b$ un empresari mèdic d'origen català amb residència a Madrid. ${ }^{55}$

La seua memòria a València fou perpetuada gràcies a les referències a $L a$ falla de la Margot a El Pueblo i a La Chala, hereva de La Traca, durant l'època de la Segona República espanyola. Posteriorment, ja en democràcia, n'han fet ressò alguns dels volums dedicats a la història de les falles, una tasca que ha prosseguit en els últims anys. ${ }^{56}$

En conclusió, la cupletista Adela Margot va allotjar algunes de les característiques i contradiccions de la societat valenciana del seu temps al voltant del món de l'espectacle, amb una participació activa dels mitjans de comunicació en la construcció dels discursos. Simultàniament, la trajectòria vital de l'artista ens mostra la rellevància que les celebritats locals arribaren a tindre a l'hora de construir entre el públic imaginaris propers, en interacció amb les produccions culturals idiosincràtiques del context. El seu devindre fou clau la difusió del cuplet, gràcies als usos dels recursos presents a l'àrea, al mateix temps que s'hi

51. «Un llibre de la Margot», La Traca, 09/08/1919.

52. La primera noticia de l'estada a Tenerife la trobem el 19/11/1919 al periòdic El Progreso d'aquella ciutat, apareguent-hi de forma més o menys regular fins a abril de 1920 ( $\mathrm{La}$ Prensa, 13/04/1920).

53. Castilla, 50, 01/02/1925, p. 19.

54. A partir de l'any 1927, trobem a una artista i conzonetista, de nom Adela Vicente, que recita «poesías sociales» en actes de campanyes abolicionistes en Madrid ( $\mathrm{El}$ arte de recitar versos», La Esfera, 694, p. 11 i La Libertad, 16/11/1932.

55. ABC (Madrid), 29/03/1946 i 23/03/1948.

56. El Pueblo, 17/03/1929; «Les falles», suplement de La Chala, 294, 22/02/1933 i El Pueblo, 18/03/1934. La seua memòria s'allargaria en el temps fins a l'any 2012, quan la comissió de la falla de la Plaça del Doctor Collado va dedicar-li els seus monuments en el centenari de la seua fita i en nombroses pàgines web. 
representaven acords i divergències, i s'hi intercanviaven models d'espectacle, de gènere i d'identitat territorial.

\section{Bibliografia}

ANASTASIO, Pepa (2007). ¿Género ínfimo? El cuplé y la cupletista como desafio. Journal of Iberian and Latin American Studies, 13: 2, 193-216. https://doi. org/10.1080/14701840701776322

ANASTASIO, Pepa (2009). Pisa con garbo: el cuplé como performance. TRANS: Transcultural Music Review, 13, https://www.sibetrans.com/trans/articulo/61/ pisa-con-garbo-el-cuple-como-performance

ARCHILÉS, Ferran (2002). Una nacionalización no tan débil: patriotismo local y republicanismo en Castellón (1891-1910). Ayer, 48, 283-312.

ARCHILÉS, Ferran; GARCÍA CARRIÓN, Marta (2012). En la sombra del estado. Esfera pública nacional y homogeneización cultural en la España de la Restauración. Historia Contemporánea, 45, 483-518.

ARESTI ESTEBAN, Nerea (2007). La mujer moderna, el tercer sexo y la bohemia en los años veinte. Dossiers feministes, 10, 173-185 https://raco.cat/index.php/ DossiersFeministes/article/view/102546

ARIÑO VILLARROYA, Antonio (1992). La ciudad ritual. La fiesta de las Fallas. Barcelona: Anthropos.

ARIÑO VILLARROYA, Antonio et al. (1990). Historia de las fallas. Valencia: Levante.

BLASCO MAGRANER, José Salvador; BUENO CAMEJO, Francisco (2015). La crisis teatral en Valencia a principios del siglo XX. Quadrivium, 6 https://avamus.org/ wp-content/uploads/2016/02/04_Blasco-Magraner_Bueno-Camenjo.pdf.

BOJÓ MOLINA, Noelia (2019). Regionalismo y blasquismo en la obra de Luis Sánchez Fernández y Ricardo Rodríguez: Una aproximación al esquet valenciano a partir de La purea del amor o Els resultats del carnestoltes. Quadrivium, 10, https://avamus.org/wp-content/uploads/2020/04/QDV-Noelia-Boj\%C3\%B3.pdf

CARCEL ORTÍ, Vicente (2004). Negociaciones hispano-vaticanas sobre la «Ley del Candado». Documentación diplomática esencial de 1911 a 1913. Analecta sacra tarraconensia, 77, 309-480 https:/www.bibliotecabalmes.cat/content/ negociaciones-hispano-vaticanas-ley-del-candado-documentacion-diplomatica-esencial-1911-1913

COMES IGLESIA, Vicente (1992). La aparición de «Diario de Valencia» (1911): un factor dinamizador del catolicismo político valenciano. En Antonio LAGUNA PLATERO, Andreu LÓPEZ BLASCO (coords.). Dos-cents anys de prensa valenciana (205-216). València: Generalitat Valenciana.

CLÚA, Isabel (2016). Cuerpos de escándalo: celebridad femenina en el fin-de-siècle. Barcelona: Icaria. 
DYER, Richard ([1979] 2001). Las estrellas cinematograficas: historia, ideologia, estètica. Barcelona: Paidós.

ENCABO, Enrique (2014). Consuelo Vello, La Fornarina (1884-1915): La divina erótica, la refinada sicalíptica. En Patricia CIFRE WIBROW, Manuel GONZÁLEZ DE ÁVILA (coord.). Culturas de la seducción (251-258). Salamanca: Universidad de Salamanca.

ENCABO, Enrique (2019a). Introducción. En Enrique ENCABO (ed.), Miradas sobre el cuplé en España: identidades, contextos, artistas y repertorios (9-38). Madrid: ICCMU.

ENCABO, Enrique (2019b). Cuerpos que cantan, cuerpos que cuentan: la Fornarina y la encarnación del deseo. En Enrique ENCABO (ed.), Miradas sobre el cuplé en España: identidades, contextos, artistas y repertorios (65-78). Madrid, ICCMU.

FERRIS, Karry O. (2010). The Next Big Thing: Local Celebrity. Society, 47, 392-395. https://doi.org/10.1007/s12115-010-9349-8

GALBIS LÓPEZ, Vicente (1997). La zarzuela en el área mediterránea. Cuadernos de música iberoamericana, 2, 327-350.

GARCIA BALlESTEROS, Marcial (1996). Mariano Pérez Sánchez. 80 años de música requenense. Requena: Centro de Estudios Requenenses, Ayuntamiento de Requena.

GARCÍA CARRIÓN, Marta (2015). La regió en la pantalla. El cinema i la identitat dels valencians. Catarroja: Afers.

GARCÍA CARRIÓN, Marta (2017). Peliculera y española. Raquel Meller como icono nacional en los felices años veinte. Ayer, 106, 159-181 https://revistaayer. com/sites/default/files/articulos/106-6-ayer106_generoynacion.pdf

GÓMEZ GASCÓN, Carmelo (1917). Cremáes sinse fóc: sainete valensiá en un acte, en vers y prosa, inspirat sobre el resibiment que li feren les dones en un poble de la provincia de Castelló a la chenial artista Adela Margot. Tarragona: Impremta de Llorens i Cabré.

MARGOT, Adela (1919). Al oído. El libro de la vida. Madrid: Imp. de la Viuda de Luis Tasso.

MARSHALL, David P. ([1997] 2014). Celebrity and Power. University of Minnesota Press. https://doi.org/10.5749/minnesota/9780816695621.001.0001

MEDINA BONILLA, Juanjo; SANCHIS AMBRÓS, Manuel (2012). Ara fa un segle. Les falles de la València de 1912. Llibret de la Festa de Lletres Falleres 2012, 16-30 https://issuu.com/lletresfalleres/docs/llibret_lletresfalleres

MENDOZA MARTÍN, Irene (2018). Las glorias del espectáculo. Actrices y celebridad en el primer tercio del siglo XX español, Ayer, 112: 213-236 https:// revistaayer.com/sites/default/files/articulos/09\%20Mendoza\%20Martin\%20 Ayer\%20112.pdf 
MONLLEÓ PERIS, Rosa (2007). Cultura urbana femenina. Espacios de ocio en Castellón a finales del siglo XIX. Dossiers feministes, 10, 121-172 https://raco. cat/index.php/DossiersFeministes/article/view/102543

MOLNER, Eduard (2017). El Paral-lel fent país: Impacte i percepció de l'oferta escènica del Paral-lel 1892-1936. Tesi doctoral. Barcelona: Universitat de Barcelona http://diposit.ub.edu/dspace/handle/2445/116494

NAVARRO, Laura (2015). Angeles Caidos: Cupletismo y Prostitución en Barcelona (1880-1936). Tesi doctoral. Columbus: The Ohio State University http://rave. ohiolink.edu/etdc/view?acc_num=osu1434261401

PLANAGUMÀ-CLARÀ, Laura (2020). Del Paral-lel al centro: triunfo y proyección de Raquel Meller (1911-1912). Etno: Cuadernos de Etnomusicología, 15, 70-97.

SALAÜN, Serge (1990). El cuplé (1900-1936), Madrid: Espasa Calpe.

SANFELIU GIMENO, Luz (2002). Republicanismo y modernidad. El Blasquismo (1895-1910): Proyecto político y transformación de las identidades subjetivas. Tesi doctoral. València: Universitat de València http://hdl.handle.net/10550/38482

SANFELIU GIMENO, Luz (2005). Republicanas. Identidades de género en el Blasquismo (1895-1910). València: PUV.

SOLER GODES, Enric (1978). Las fallas de Valencia: 1849-1977. València: [Lautor].

ZUBIAURRE, Maite (2014). Culturas del erotismo en España 1898-1939. Madrid: Cátedra. 